\title{
PENGARUH FAKTOR-FAKTOR PEREKONOMIAN MAKRO \\ TERHADAP KINERJA REKSADANA PENDAPATAN TETAP PERIODE 2015-2017
}

\section{THE EFFECT OF MACRO ECONOMIC FACTORS TOWARD PERFORMANCE OF FIXED INCOME MUTUAL FUNDS DURING 2015-2017}

\author{
Setya Ayu Rahmawati \\ Dudung Ma'ruf Nuris \\ Universitas Negeri malang \\ setyaayu.rahmawati@gmail.com
}

\begin{abstract}
Abstrak: Pengaruh Faktor-Faktor Perekonomian Makro Terhadap Kinerja Reksadana Pendapatan Tetap Periode 2015-2017. Penelitian in bertujuan untuk mengetahui pengaruh faktor-faktor perekonomian makro terhadap kinerja reksadana pendapatan tetap. Indikator makro ekonomi yng digunakan adalah indeks suku bunga SBI, nilai tukar rupiah, harga minyak dunia, dan tingkat inflasi dengan periode data penelitian pada 2015-2017. Penelitian ini merupakan penelitian explanatory dengan 30 sampel yang terdaftar di OJK dan diolah menggunakan analasis regresi berganda. Hasil pengujian menunjukkan bahwa hipotesis diterima yaitu variable makro memberikan pengaruh pada kinerja reksadan tetap baik secara simultan maupun parsial.
\end{abstract}

Kata kunci: reksadana pendapatan tetap, indeks suku bunga SBI, nilai tukar Rupiah, harga minyak dunia, inflasi

Abstract: The Effect of Macro Economic Factors Toward Performance of Fixed Income Mutual Funds during 2015-2017. This study aim was determining the influence of macro economic factors towards performance of fixed income mutual funds. Macro economic indicators used in this study were represented by SBI interest rate, exchange rate of Rupiah, world oil prices, and inflation whit data periods since 2015 to 2017. This research was explanatory research which used 30 samples recorded by OJK and processed using regression analysis. The results showed that all the hypothesis was accepted that in detail, all the macro variable tested in this study proven affected the performance of fixed income mutual funds simultaneously and partially.

Keywords: fixed income mutual funds, SBI interest rate, exchange rate of Rupiah, world oil prices, and inflation

\section{PENDAHULUAN}

Reksadana sebagai salah satu instrument investasi yang populer merupakan salah satu alternatf bagi investor pemula dan pemodal kecil untuk bertransaksi di pasar modal. Kepopuleran reksadana didukung oleh keunggulan yang dimiliki, diantaranya instrument ini dirasa memberikan kemudahan dan efisiensi waktu dan biaya serta resiko yang relatif lebih rendah. Hal ini dikarenakan adanya diversifikasi investasi yang terwujud dalam portofolio. Namun demikian investasi reksadana ini bukanlah kebal resiko karena masih melekat di 


\section{JURNAL NOMINAL / VOLUME VII NOMOR 2 / TAHUN 2018}

dalamnya potensi penurunan nilai unit penyertaan akibat pengaruh internal maupun eksternal.

Resiko eksternal yang dapat mempengaruhi nilai aktiva bersih dapat dilihat dari dampak yang diakibatkan oleh kondisi makro ekonomi. Seperti Indonesia yang telah mengalami krisis ekonomi besar pada 1998 dan 2008 masing-masing dipicu oleh overshooting nilai dollar dan kasus subprime mortage yang mengarah pada kredit macet massal. Kejadian ekonomi luar biasa ini turut serta dirasakan oleh Indonesi yang kala itu harus menanggung pelemahan rupiah hingga menembus nilai bahkan lebih dari Rp.15.500 untuk US\$ 1 (www.klikbca.com). Secara masiv dampaknya mengarah pada kebijakan pemutusan kerja oleh perusahaanperusahaan, harga minyak yang fluktuatif, dan lonjakan suku bunga. Hal ini menjadi refleksi besarnya pengaruh dunia investasi terhadap kondisi perekonomian national yang secara langsung memberi dampak pada investor suatu negara.

Sebagai salah satu pertimbangan dalam berinvastasi, faktor-faktor ekonomi makro tersebut perlu mendapatkan perhatian dalam pengambilan keputusan, salah satunya dalam instrument reksadana. Meskipun dinilai sebagai instrument yang cukup rendah resiko, investor reksadana tidak dapat menghindari besarnya pengaruh resiko ekonomi makro ini terhadap unit penyertaannya. Menurut instrument investasinya secara umum reksadana dapat dibagi menjadi reksadana saham, reksadana pasar uang, reksadana tetap reksadana campuran (Manurung, 2007). Khusus reksadana pendapatan tetap, faktor makro ekonomi mendapatkan perhatian yang besar mengingat sebagian besar komponen investasinya ditempatkan dalam bentuk obligasi yang pergerakannya dipengaruhi oleh suku bunga.

Penelitian ini mencoba berfokus pada kinerja reksadana tetap yang dipengaruhi oleh beberapa faktor makro ekonomi utama. Reksadana tetap dengan obligasi sebagai komponen utamanya dapat menjadi salah satu indikator untuk menilai sensitifitas faktor ekonomi terhadap instrument investasi tersebut. Faktor ekonomi yang dipilih adalah yang dirasa cukup merepresentasikan kondisi perekonomian makro suatu negara (wibowo, 2011; Sholihat dkk, 2015) yaitu suku bunga Bank Indonesia, inflasi, kurs nilai tukar rupiah, dan harga minyak dunia. Selain itu penelitian ini mengambil basis data 2 tahun sebelum 2018 dengan pertimbangan antisipasi terhadap kekhawatiranterjadinya siklus krisis 10 tahunan setelah sebelumnya 


\section{JURNAL NOMINAL / VOLUME VII NOMOR 2 / TAHUN 2018}

terjadi pada 1998 dan 2008, yang berpengaruh pada potensi penurunan investasi.

\section{KAJIAN LITERATUR}

\section{Reksadana Pendapatan Tetap}

Unit trust dan mutual fund atau investment fund adalah istilah-istilah yang memiliki pengertian sama dengan reksadana, yaitu bentuk investasi kolektif yang memungkinkan bagi investor yang memiliki tujuan investasi sejenis untuk mengumpulkan dananya agar dapat diinvestasikan dalam bentuk portofolio yang dikelola oleh fund manager.

Pengelolaan dana kolektif masyarakat ini dapat diinvestasikan pada beberapa jenis reksadana. Menurut UU No. 8 tahun 1995 tentang pasar modal, reksadana dapat dibedakan berdasarkan jenis instrumennya ke dalam kelompok reksadana pasar uang, reksadana saham, reksadana campuran, dan reksadana pendapatan tetap.

Reksadana yang dana penyertaannya diinvestasikan sekurangkurangnya $80 \%$ dari portofolionya ke dalam efek bersifat hutang disebut sebagai reksadana pendapatan tetap. Efek bersifat hutang ini, yang umumnya memberikan penghasilan dapam bentuk bunga, dapat berupa deposito, SBI, obligasi. Di Indonesia, reksadana tetap umumnya menjadikan obligasi sebagai komponen utamanya yaitu surat utang atau janji pembayaran untuk jangka waktu tertentu dan dikeluarkan oleh peminjam yang berjanji untuk membayarkan bunga tertentu setiap tahun pada pemegangnya (Keown dkk, 2005). Obligasi yang dikeluarkan oleh tertentu untuk mendapatkan pinjaman tunai ini (Bodie dkk, 2005), dinilai memiliki tingkat resiko internal yang rendah karena kepastian pembayarannya yang tinggi.

Reksadana pendapatan tetap mengalami perkembangan yang cukup pesat dari tahun ke tahun hingga tahun 2017 tercatat berjumlah 223 produk.

\section{Kinerja Reksadana}

Pada reksadana, manajemen investasi mengelola dana-dana yang ditempatkan pada surat berharga dan merealisasikan keuntungan ataupun kerugian termasuk penerimaan deviden dan bunga yang dibukukan dalam nilai aktiva bersih (NAB) reksadana tersebut. Pengukuran kinerja reksadana yang didasarkan atas NAB ini dapat dihitung dengan tiga rasio menggunakan dasar Capital Assets Pricing Model (CAPM) yaitu reward to variability, reward to volatility, dan differential return measure. Untuk penelitian ini menggunakan metode pengukuran rasio reward to variability (Sharpe, 1995), dengan formula: 
JURNAL NOMINAL / VOLUME VII NOMOR 2 / TAHUN 2018

\[ \text { Spi }=\frac{R p i-R f}{S D p i} \]
Spi $=$ indeks Sharpe
portofolio i
Rpi $=$ rata-rata tingkat
pengembalian portofolio i

$\mathrm{Rf} \quad=$ rata-rata atas bunga investasi bebas resiko

SDpi $=$ premi resiko portofolio i

Rasio Sharpe ini merupakan perbandingan antara premi resiko terhadap total yang dinyatakan dalam deviasi standar. Raksadana yang memiliki kinerja diatas portofolio pasar menunjukkan bahwa reksadana tersebut superior (baik), sedangkan reksadana yang memiliki kinerja dibawah portofolio pasar menunjukkan kinerja yang inferior.

Penghitungan rasio sharpe ini membutuhkan informasi awal berupa Nilai Aktiva Bersih (NAB) . data NAB per unit setiap reksadana pendapatan tetap berasal dari situs www.ojk.go.id dimana dengan periode data dari mei 2015 sampai april 2017.

\section{Indeks Suku Bunga SBI}

Jumlah yang diterima oleh pihak pemberi pinjaman dan dibayarkan oleh peminja disebut sebagai suku bunga (Mc.Taggart, 2003). Suku bunga yang berbentuk prosentase yield ini merupakan salah satu faktor pertimbangan dalam membuat keputusan investasi karena merepresentasikan hubungan masa kini dan masa depan.

Salah satu barometer makro ekonomi yang berpengaruh terhadap kinerja perusahaan secara langsung adalah tingkat suku bunga domestic, atau dalam hal ini suku bunga SBI (Samsul, 2006). Perubahan suku bunga SBI dapat mempengaruhi variabilitas dari suatu investasi. Hal ini dapat terjadi karena jika suku bunga meningkat, maka harga saham akan cenderung turun, begitu pula sebaliknya. Dengan alasan tingkat keuntungan yang diharapkan atas saham kecil dibandingkan dengan keuntungan dari tingkat suku bunga sehingga mengakibatkan penurunan permintaan terhadap saham dan dampaknya harga sahan menurun seiring kenaikan suku bunga tersebut (Haryanto, 2007).

Penelitian ini menggunakan data dari Bank Indonesia untuk mendokumentasikan pergerakan tingkat suku bunga SBI

\section{Nilai Tukar Rupiah}

Kurs merupakan nilai tukar mata uang suatu negara terhadap mata uang negara lain (Hasibuan, 2005). Mata uang internasional yang sering kali dijadikan standar mata uang negara-negara di dunia adalah Dollar Amerika (USD). Hal ini dikarenakan USD memiliki nilai tukar yang relatif konstan terhadap mata 


\section{JURNAL NOMINAL / VOLUME VII NOMOR 2 / TAHUN 2018}

uang manapun (Fatahillah, 2008). Penelitian Haryanto dan Riyanto (2007) sejalan dengan Astutik (2005) yang menguatkan pandangan bahawa nilai tukar mata uang berpengaruh terhadap resiko sistematik di pasar modal.

\section{Harga Minyak Dunia}

Harga minyak dunia merupakan satu faktor penting dalam perekonomian di suatu nefara termasuk Indonesia. Hal ini dikarenakan tidak ada satu negara yang mampu menurunkan konsumsinya terhadap minyak untuk kebutuhan energinya (Surjadi, 2006) Ketergantungan terhadap minyak sebagai sumber energi ini akibat belum sempurnanya pengelolaan perdagangan minyak pada mekanisme pasar sepenuhnya, subsidi minyak masih menjadi beban negara, ketidakberhasilan efisiensi energi dan energi alternatif. Dalam dunia investasi, gejolah perekonomian akibat kenaikan harga minyak dunia akan memberikan dampak bagi kinerja instrument investasinya (Wahyuningsih, 2008). Data harga minyak dunia yang digunakan dalam penelitian ini adalah data minya dunia bulanan yang diperoleh dari situs resmi OPEC (Organization of the Potrelium Exporting Countries) www.opec.org.

\section{Tingkat Inflasi}

Inflasi adalah suatu keadaan dimana secara umum harga-harga melambung tinggi dan nilai dari uang tersebut mengalami penurunan (McTaggart, 2003). Jika inflasi meningkat maka nilai uang menurun dan dapat menyebabkan penurunan daya beli masyarakat. Menurut Sunariyah (2011 : 21), meningkatnya inflasi secara relatif adalah signal negatif bagi investor. Data statistik di penelitian ini menggunakan data presentase perubahan mingguan indeks harga konsumen di kota-kota Indonesia berdasarkan data statistik BPS

\section{METODE PENELITIAN}

Penelitian ini merupakan penelitian penjelasan (explanatory research) yang mencoba menjelaskan aspek terjadinya sebuah hubungan atau memastikan terjadinya perbedaanperbedaan diantara beberapa variable ataupun independensi dua faktor atau lebih dalam sebuah situasi (Sekaran, 2002) . Dimensi waktu yang digunakan adalah Mei 2015 - April 2017 dengan dasar pertimbangan prediksi masa awal siklus tahunan krisis keuangan. Data yang digunakan adalah data sekunder yang metode pengumpulannya dengan menggunakan metode dokumentasi dari berbagai literature, majalah, dan internet.

Data yang telah didokumentasikan kemudian diolah dengan menggunakan metode statistik yaitu meride regresi berganda dengan 


\section{JURNAL NOMINAL / VOLUME VII NOMOR 2 / TAHUN 2018}

tujuan untuk melihat keeratan hubungan satu variable dengan beberapa variable independen serta untuk menaksir harga variable dependen. Regresi

berganda digunakan untuk meramalkan fluktuasi (keadaan naik turunnya) variabeldependen (Kriterium), bila dua atau lebih variabel independen sebagai faktor predictor dimanipulasi (dinaikturunkan nilainya). Hubungan antar variable ini dila dinotasikan dalam rumus menjadi sebagai berikut:

Model : $Y_{1}=\beta_{0}+\beta_{1}$. SBI $+\beta_{2}$. KURS + $\beta_{3 .}$ OIL $+\beta_{4 . I N F L}+\mathrm{e}$

Dengan :

Yi $=$ variabel eksogen (dependen Variabel ) $=$ Tingkat Imbal Hasil Reksadana Pendapatan Tetap

$\mathrm{Xj} \quad=$ variabel endogen (independen Variabel) yaitu:

SBI = tingkat suku bunga SBI

KURS $=$ Tingkat Perubahan Nilai Kurs Rupiah terhadap Dollar Amerika

DOIL $=$ Tingkat Perubahan Harga Minyak Bumi Dunia

INFL = Tingkat Inflasi

$\mathrm{B}_{0} \quad=$ Intersep

$\mathrm{B}_{\mathrm{j}} \quad=$ koefisien regresi (slope dari garis regresi) yang mengukur besarnya pengaruh

$\mathrm{e}=$ error term $=$ gangguan/disturbance

Hipotesis
$\mathrm{H}_{1}$ : perubahan suku bunga SBI memiliki pengaruh terhadap kinerja reksadana pendapatan tetap

$\mathrm{H}_{2}$ : perubahan nilai tukar Rupiah memiliki pengaruh terhadap kinerja reksadana pendapatan tetap

$\mathrm{H}_{3}$ : perubahan harga minyak dunia memiliki pengaruh terhadap kinerja reksadana pendapatan tetap

$\mathrm{H}_{4}$ : perubahan inflasi memiliki pengaruh terhadap kinerja reksadana pendapatan tetap

\section{HASIL PENELITIAN DAN} PEMBAHASAN

proses pengumpulan data pada penelitian ini dilakukan dengan memiliki produk reksadana pendapatan tetap yan sesuai dengan kriteria sampel yang dibutuhkan yaitu reksadana yang terdaftar di OJK. Sebelum pengujian hipotesis dilakukan terlebih dahulu pengujian aasumsi klasik untuk memastikan persyaratan pra analisis.

\section{Uji Prasyaratan Analisis}

\section{Uji Normalitas}

Uji normalitas adalah pengujian yang digunakan untuk mengetahui apakah data variabel berdistribusi normal atau tidak. Menurut Ghozali (2011) model regresi yang baik adalah memiliki distribusi data normal atau mendekati normal. Pengujian normalitas ini dilakukan dengan menggunakan uji 


\section{JURNAL NOMINAL / VOLUME VII NOMOR 2 / TAHUN 2018}

Kolmogorov-Smirnov yang dalam penelitian ini menunjukkan nilai signifikasi 0,131 dan dinyatakan berdistribusi normal.

\section{Uji Heterokedastisitas}

Uji heterokedastisitas digunakan untuk menguji apakah dalam sebuah model regresi terjadi ketidaksamaan varian dari residual pada satu pengamatan ke pengamatan lain. Dengan menggunakan pengamatan grafit scatterplot diketahui bahwa data bebas dari gejala heterokedastisitas.

Penilaian nilai absolut residual hasil regresi juga digunakan untuk memastikan hal ini . hasil regresi yang digunakan mennjukkan nilai signifikansi lebih dari 0,05 sehingga asumsi nonheterokedastisitas telah terpenuhi.

\section{Uji Autokolerasi}

Metode uji autokolerasi digunakan untuk mengetahui apakah dalam suatu model regresi liner ada korelasi antara kesalahan pengganggu pada periode $\mathrm{t}$ dan $\mathrm{t}-1$. Pemeriksanaan yang dilakukan dengan menggunakan metode Durbin Watson menunjukkan nilai sebesar 1.981 yang berarti telah terpenuhi.

\section{Uji Multikolinieritas}

Untuk mengetahui ada tidaknya hubungan antar variable ini dilakukan dengan menggunakan nilai VIF (Variance Inflation Factor). Hasil regresi menunjukan nilai VIF lebih kecil dari angka 5 sehingga disimpulkan asumsinon-multikolinieritas telah terpenuhi.

\section{Uji Hipotesis}

Berdasarkan uji hipotesis dengan menggunakan alat metode regresi linier berganda maka dapat diketahui bahwa tingkat suku bunga SBI, nilai tukar rupiah, tingkat harga minyak dunia dan tingkat inflasi secara simultan berpengaruh signifikan terhadap kinerja reksadana pendapatan tetap.

Tabel 1. Hasil Analisis Regresi Uji F

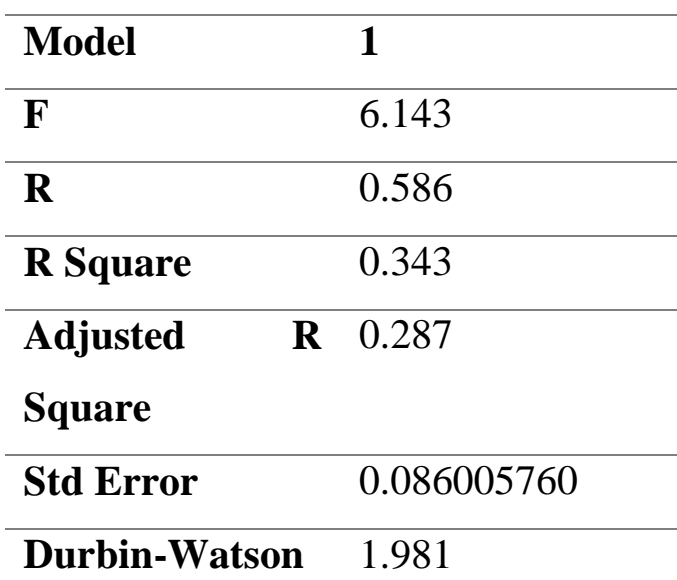

Sumber: dara sekunder yang diolah, 2017

Dari tabel di atas, hasil analisis regresi (uji F) untuk model penelitian ini menunjukkan nilai adjusted $\mathrm{R}$ Square = 0,287 yang menunjukkan bahwa perubahan kinerja reksadana pendapatan tetap (Y) dapat dijelaskan oleh persamaan regresi sebesar $28,7 \%$.Variabel return dipengaruhi sebesar 34,3\% oleh variable Suku Bunga SBI, inflasi, nilai tukar rupiah dan harga 
JURNAL NOMINAL / VOLUME VII NOMOR 2 / TAHUN 2018

minyak dunia. Dari tabel di atas pula dapat telihanilai $\mathrm{F}$ hitung adalah 6,143 yang lebih besar dari $\mathrm{F}$ tabel dengan nilai signifikansi alfanya sebesar $0,000<$ 0,05 . Sehingga dapat disimpulkan bahwa faktor-faktor makro ekonomi secara simultan berpengaruh signifikan terhadap kinerja reksadana pendapatan tetap.

Untuk pengujian apakah variable bebas secara individu mempunyai pengaruh yang signifikan terhadap variable terikat nampak pada tabel di bawah ini:

Tabel 2. Hasil Uji T hitung dan T tabel

\begin{tabular}{|c|c|c|c|c|}
\hline $\begin{array}{l}\text { Var } \\
\text { beba }\end{array}$ & $\begin{array}{l}\text { T } \\
\text { hitun }\end{array}$ & $\begin{array}{l}T \\
\text { tabe }\end{array}$ & Sig & Status \\
\hline $\mathbf{S}$ & g & 1 & & \\
\hline \multirow[t]{3}{*}{$X_{1}$} & 2,396 & 1,67 & 0,02 & $\mathrm{H}_{0}$ \\
\hline & & 7 & 1 & Ditola \\
\hline & & & & $\mathrm{k}$ \\
\hline \multirow[t]{3}{*}{$\mathbf{X}_{2}$} & 3,514 & 1,67 & 0,00 & $\mathrm{H}_{0}$ \\
\hline & & 7 & 1 & Ditola \\
\hline & & & & $\mathrm{k}$ \\
\hline \multirow[t]{3}{*}{$\mathbf{X}_{3}$} & 4,841 & 1,67 & 0,00 & $\mathrm{H}_{0}$ \\
\hline & & 7 & 0 & Ditola \\
\hline & & & & $\mathrm{k}$ \\
\hline \multirow[t]{3}{*}{$\mathbf{X}_{4}$} & 3,789 & 1,67 & 0,00 & $\mathrm{H}_{0}$ \\
\hline & & 7 & 0 & Ditola \\
\hline & & & & $\mathrm{k}$ \\
\hline
\end{tabular}

Sumber: data sekunder yang diolah, 2017

Adapun hasil pengujian hipotesis diuraikan debagai berikut:
Pengaruh tingkat suku bunga SBI terhadap kinerja reksadana pendapatan tetap

Hasil analisis regresi menunjukkan tingkat suku bunga SBI berpengaruh signifikan terhadap kinerja reksadana pendapatan tetap. Hasil ini konsisten dengan penelitian Tanamas (2006) dan Chrystanty (2004) yang menyatakan bahwa tingkat suku bunga memperngaruhi kinerja investasi khususnya reksadana pendapatan tetap. Adanya pengaruh yang signifikan ini menunjukkan perubahan suku bunga SBI memiliki keterkaitan dengan kecenderungan masayarakat dalam melakukan invetasi.

Pengambilan keputusan investasi ini Nampak pada perilaku investor yang cenderung menempatkan dananya pada instrument yang lebih menguntungkan akibat adanya kenaikan suku bunga seperti obligasi dan deposito yang merupakan komponen utama reksadana pendapatan tetap. Hal ini disebabkan karena investor akan cenderung memilih investasi yang rendah resiko dan menjanjikan keuntungan yang besar.

Pengaruh nilai tukar rupiah terhadap kinerja reksadana pendapatan tetap

Pergerakan nilai tukar rupiah terhadap dollar sering kali menunjukkan karakter fluktuatif, semikian halnya pada periode pngamatan ini. Banyak faktor 


\section{JURNAL NOMINAL / VOLUME VII NOMOR 2 / TAHUN 2018}

yang mempengaruhi namun dalam penelitian ini tingkat suku bunga mengambil peranan penting. Kondisi ini muncul karena peranan pemerintah dalam mengatur peredaran uang melalui penentuan suku bunga.

Perubahan kurs mata uang rupiah juga dapat dilihat pengaruhnya melalui resiko sistematis atas pergerakan investasi di pasar modal (Haryanto, 2007). Seperti dalam hasil analisis regresi di penelitian ini yang menunjukkan korelasi yang kuat utamanya pada entitas-entitas yang ada kaitannya dengan hubungan luar negeri.

\section{Pengaruh harga minyak dunia terhadap kinerja reksadana pendapatan tetap}

Kondisi perekonomian suatu negara sangat sensitive terhadap pergerakan harga minyak karena menjadikan minya sebagai komoditienergi utama dalam produksinya. Bahkan kecenderungannya megarah pada kenaikan yang konsisten akibat kelangkaan komoditas ini.

Pada penelitian ini, hasil regresi menunjukkan harga minyak dunia memang berpengaruh terhadap kinerja reksadana pendapatan tetap. Hasil ini konsisten dengan penelitian Tanamas (2006) dan Wahyuningsih (2008).

Pengaruh tingkat inflasi terhadap kinerja reksadana pendapatan tetap
Reksadana pendatan tetap dalam penelitian ini menunjukkan kondisi terdampak atas tingkat inflasi yang terjadi di Indonesia. Hasil ini konsisten dengan penelitian Tanamas (2006) yang menyatakan bahwa inflasi menjadi faktor ekonomi makri yan erat kaitannya dengan kinerja reksadana tetap.

Lebih jauh lagi, Setiaji (2008) menjelaskan bahwa dampak inflasi terhadap portofolio investasi sangat bergantung pada jenis instrumennya termasuk reksadana tetap. Hal ini dikarenakan sebagian besar instrument incestasi yang ditawarkan pada reksadan pendapatn tetap adalah obligasi yang memiliki keterkaitan kuat pada suku bunga.

\section{PENUTUP}

Beberapa kesimpulan yang dapat diambil dari hasil penelitian ini yaitu:

1. secara simultan, variable suku bunga SBI, nilai tukar Rupiah, harga minyak dunia, dan inflasi berpengaruh signifikan terhadap kinerja reksadana pendapata tetap. Hal ini menunjukkan bahwa keempat variable tersebut terbukti dapat mempengaruhi kinerja dari reksadana pendapatan tetap yang diukur beradasarkan return.

2. Secara partial, hasil pengujian hipotesis 1 menunjukkan variable 


\section{JURNAL NOMINAL / VOLUME VII NOMOR 2 / TAHUN 2018}

suku bunga SBI berpengaruh signifikan terhadap reksadana pendapatan tetap. Hal ini menunjukkan bahwa kinerja reksadana pendapatan tetap terpengaruh dengan tingakt suku bunga SBI. Pengaruh ini disebabkan karena instrument utama dari reksadana pendapatan tetap adalah obligasi yang memiliki sensitifitas tinggi terhadap suku bunga,

3. Secara partial, hasil pengujian hipotesis 2 menunjukkan variable nilai tukar Rupiah berpengaruh signifikan terhadap reksadana pendapatan tetap. Nilai tukar Rupiah terhadap Dollar yang digunakan dalam penelitian ini menjadi bukti bahwa kurs mata uang memiliki pengaruh terhadap kinerja reksadana pendapatan tetap dikarenakan banyak emiten-emiten dalam portofolio yang memiliki hubungan luar negeri dalam transaksinya.

4. Secara partial, hasil pengujian hipotesis 3 menunjukkan variable harga minyak dunia berpengaruh signifikan terhadap reksadana pendapatan tetap. Pergerakan harga minyak dunia mempengaruhi kinerja reksadana tetap akibat komoditas ini menjadi sumber energi utama bagi hampir semua perusahaan.

5. Secara partial, hasil pengujian hipotesis 4 menunjukkan variable inflasi berpengaruh signifikan terhadap reksadana pendapatan tetap. Inflasi mempengaruhi reksadana tetap melalui penurunan daya beli masyarakat maupun kenaikan suku bunga.

\section{DAFTAR PUSTAKA}

Astuti, Wahyu Widya (2004). “Analisis Hubungan Cash Flow dari Aktivitas Operasi, Investasi, dan Pendanaan serta Agregat Accruals terhadap Return Saham". Tesis: Universitas Brawijaya.

Bodie Kane et.al (2005). "Investment $6^{\text {th }}$ Edition. New York: Irwin

Fatahillah (2008). "Pengaruh Perubahan Rezim Nilai Tukar Rupiah terhadap Laju Inflasi dan Kurs”. Tesis: Universitas Gajahmada

Ghozali. Imam (2011). Aplikasi Analisis Multivariate Dengan Program SPSS 19. Semarang: Badan Penerbit Universitas Diponegoro.

Haryanto, Desi dan Riyanto (2007). "Pengaruh Suku Bunga Sertifikat Bank Indonesia dan NIlai Kurs terhadap Resiko Sistematis Perusahaan di BEJ. Jurnal Keuangan dan Bisnis. Vol5: 2440

Hasibuan, SP Malayu (2005) "DasarDasar Perbankan”. Jakarta: Bumi Aksara 
Keown, Arthur J et.al (2005). "Financial Management: Principal and Applications $10^{\text {th }}$ Edition". USA: Pearson-Prentice Hall

Manurung, Adley Haymans (2007). "Panduan Lengkap Reksadana Investasiku". Jakarta: Kompas.

Samsul, Mohamad (2006). "Pasar Modal \& Manajemen Portofolio". Jakarta: Erlangga

Sharpe, William F (1995). "Investment diterjemahkan oleh Henry Njoo." Jakarta: Prenhealindo

Sholihat, Fatharani dan Moch Dzulkiron (2015). "Pengaruh Inflasi, Tingkat Suku Bunga Sertifikat Bank Indonesia \& Indeks Harga Saham Gabungan Terhadap Tingkat Pengembalian Reksadana Saham (Studi Pada Bursa Efek Indonesia Periode 2011 - 2013). Jurnal Administrasi Bisnis (JAB) Vol. 21 No. 1 April 2015|
Sunariyah (2011). "Pengantar Pengetahuan Pasar modal, edisi keenam". Yogyakarta: UPP STIM YKPN

Surjadi, A.J (20404). "Masalah Dampak Tingginya Harga Minyak terhadap Perekonomian". Jakarta:SCIS

Tanamas, Homan (2006). “Analisis Kinerja Reksadana Pendapatan Tetap Seputar Krisis 2005". Tesis: Universitas Bina Nusantara

Wahyuningsih, Endang (2008). "Pengaruh Kenaikan Harga Minyak Dunia dengan Investasi”. (online: www.wealthindonesia.com)

Wibowo, Andi (2011). "Pengaruh Variabel Makro Ekonomi Terhadap Kinerja Reksadana Pendapatan Tetap Di Indonesia”. JAMBSP Vol. 7 No. 2 - Pebruari 2011: 163-182 